\title{
Infection of Cultured Human Pancreatic B Cells with Reovirus Type 3
}

\author{
J. W. Yoon, S. Selvaggio, T. Onodera, J. Wheeler, and A. B. Jenson \\ Laboratory of Oral Medicine, National Inștitute of Dental Research, National Institutes of Health, Bethesda, Maryland, USA
}

\begin{abstract}
Summary. The capacity of reovirus type 3 to infect insulin-producing B cells was studied in human pancreatic cell cultures. Antibody to reovirus was labelled with fluorescein isothiocyanate and antibody to insulin was labelled with tetramethyl rhodamine isothiocyanate. By using a double-labelled immunofluorescent antibody technique, it was shown that only about $6 \%$ of the insulin-containing human $\mathrm{B}$ cells in culture became infected when inoculated with unpassaged reovirus type 3 . However, by repeated passage of the virus in human pancreatic $B$ cell cultures, the percentage of infected $\mathbf{B}$ cells increased to $27 \%$, and the virus titre in cultures rose from $8.0 \times$ $10^{4} \mathrm{pfu} / \mathrm{ml}$ in the first passage, to $4.9 \times 10^{6} \mathrm{pfu} / \mathrm{ml}$ in the 5 th passage. As measured by radioimmunoassay, the intracellular immunoreactive insulin began to decrease at $24 \mathrm{~h}$ after infection. This decrease roughly paralleled the increase in virus titre. In contrast, there was relatively little change in immunoreactive insulin in cultures inoculated with unpassaged reovirus type 3 . These studies show that the ability of reovirus type 3 to infect human B cells is enhanced by serial passage in human pancreatic cell cultures and that the infection resulted in the destruction of B cells and release of insulin.
\end{abstract}

Key words: Virus-induced diabetes mellitus, human pancreatic B cell cultures, double-labelled immunofluorescent antibody staining, reovirus type 3 , virus passage.

The possibility that viruses might cause some cases of insulin-dependent diabetes (IDD) by infecting and destroying pancreatic $\mathbf{B}$ cells has received considerable attention. Of the numerous viruses implicated, mumps and members of the Coxsackie virus $B$ group (particularly B4) have been most often suggested as possible causal agents of IDD [1-6]. In a recent study, it was shown that a Coxsackie virus B4 variant, isolated from the pancreas of a 10 -year-old child who died of diabetic ketoacidosis, produced diabetes in mice by infecting and destroying $B$ cells [7].

It is difficult, however, to demonstrate in vivo that viruses replicate in human B cells and produce diabetes in man. As a practical model, an in vitro system has been developed to determine if viruses are capable of infecting human B cells. By use of a double-labelled immunofluorescent antibody technique, it has been shown that human $B$ cells grown in culture were susceptible to infection by mumps [8], Coxsackie virus B3 [9], and Coxsackie virus B4 [7].

We have previously shown that reovirus type 3 , passaged in murine pancreatic $\mathrm{B}$ cell cultures, produced an insulitis when inoculated into 1 to 2 week old mice [10]. In the present investigation, the double-labelled immunofluorescent antibody technique has been used to determine whether or not human B cells grown in culture were permissive to reovirus type 3 , and whether the capacity of the virus to infect human $B$ cells was enhanced by repeated passage in human B cell cultures. Radioimmunoassay for immunoreactive insulin was used to evaluate the effect of the infection on intracellular and extracellular insulin.

\section{Materials and Methods}

\section{Pancreatic B Cell Cultures}

Four aseptically removed human pancreases from normal subjects $17,18,24$, and 40 years old (Table 1) were obtained from the Division of Transplantation Surgery, Naval Research Medical Institute, Bethesda, Md. Monolayer cultures enriched for pancreatic $B$ cells were prepared by a technique described previously [11]. Briefly, $5 \mathrm{~g}$ of the tail of the pancreas were washed 5 to 7 times in phosphate-buffered saline without $\mathrm{Ca}^{++}$and $\mathrm{Mg}^{++}$ (PBS; $0.1 \mathrm{~mol} / 1 ; \mathrm{pH} 7.4$ ) at $4{ }^{\circ} \mathrm{C}$, and containing penicillin (400 $\mathrm{IU} / \mathrm{ml})$ and streptomycin $(100 \mathrm{mg} / \mathrm{l})$. The pancreas was minced into small pieces and $70 \mathrm{ml}$ of cold PBS was added. The tissue was 

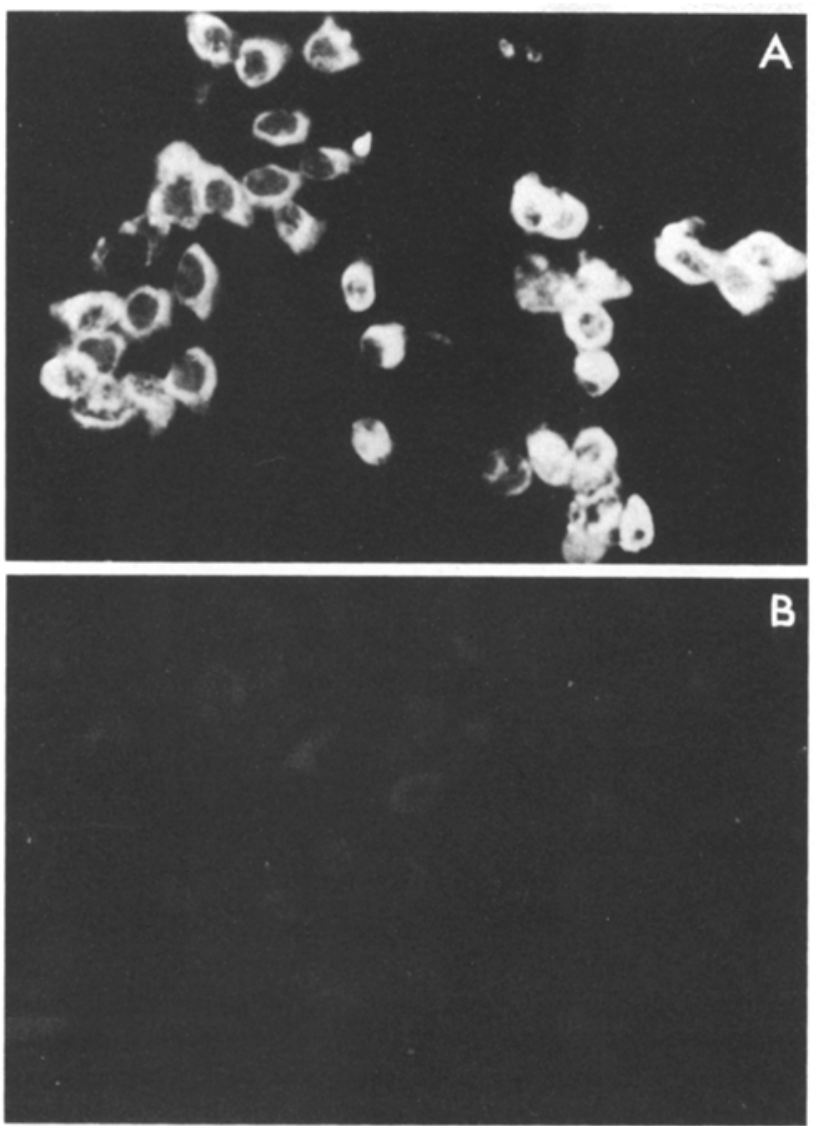

Fig. 1. A Human pancreatic cells grown on coverslips and stained with TRITC-labelled anti-insulin antibody $(\times 480)$. Specific immunofluorescence can be seen in the cytoplasm of $\mathbf{B}$ cells. B Human fibroblasts (WI-38) grown on coverslips and stained with TRITC-labelled anti-insulin antibody $(\times 480)$. None of the cells stained positively

allowed to settle for $1 \mathrm{~min}$ and the supernatant fluid containing floating debris was discarded. This procedure was repeated 15 to 20 times until pieces of pancreas less than $1.0 \mathrm{~mm}$ in diameter were obtained. The pancreatic tissue was then transferred to a flask containing $50 \mathrm{ml}$ of prewarmed collagenase solution $(12 \mathrm{mg} /$ $\mathrm{ml}$ in PBS; $190 \mathrm{U} / \mathrm{mg}$ ). Enzymatic digestion was carried out for 20 to $25 \mathrm{~min}$ at $37^{\circ} \mathrm{C}$ with vigorous shaking or magnetic stirring. The collagenase-treated material $(8 \mathrm{ml})$ was then transferred to a conical tube containing $35 \mathrm{ml}$ of PBS and centrifuged for 1 to $2 \mathrm{~min}$ at speeds just sufficient to allow the cells to settle. The supernatant fluid was carefully removed so as not to disturb the pellet. Each pellet was resuspended in fresh PBS. The cells were centrifuged and washed three more times and filtered through sterile gauze to remove large aggregates. The filtered cells then were centrifuged at $1200 \mathrm{rpm}$ for $7 \mathrm{~min}$ and the pellet was suspended in prewarmed chemically defined growth medium [MPNL $65 / \mathrm{C}[12]$ plus $7 \%$ heat-inactivated fetal calf serum] [11] and adjusted to $1.0 \times 10^{5}$ viable cells $/ \mathrm{ml}$. Plastic tissue culture dishes $(35 \mathrm{~mm})$ then were seeded with $2.5 \mathrm{ml}$ of cell suspension and incubated at $37^{\circ} \mathrm{C}$ in a humidified atmosphere of $5 \% \mathrm{CO}_{2}$. Approximately $12-15 \mathrm{~h}$ later, the non-adherent cells were decanted, thereby eliminating most of the fibroblastoid cells which had adhered to the dish. The decanted cells were seeded in $35 \mathrm{~mm}$ plastic tissue culture dishes and the end of $48 \mathrm{~h}$, the medium was replaced with fresh growth medium plus thiomersal $(0.7 \mathrm{mg} / \mathrm{litre})$ [13] (Aldrich Chemical, Milwaukee, Wisc). The cells were refed at 2 day intervals with the thiomersal containing growth media. The monolayers were then used for experiments at 5 to 12 days after culture.

For immunohistochemical staining, each $35 \mathrm{~mm}$ plastic tissue culture dish had a sterile coverslip ( $22 \mathrm{~mm}$ square Corning Glass No. 1 coverslip) placed in it. Human pancreatic cells were added to the dishes to overlay the coverslip $\left(2.5 \mathrm{ml}\right.$ containing $5 \times 10^{2}$ cells). The procedures for decantation and change of media were the same as described above. Cells grown on the coverslips for 5 days were then stained (see section on double-labelled immunofluorescent antibody technique). About 15 to $20 \%$ of the cells grown on coverslips without using the decantation step proved to be $B$ cells as evaluated by staining with tetramethyl rhodamine isothiocyanate (TRITC)- or fluorescein isothiocyanate (FITC)labelled anti-insulin antibody. In contrast, over $30 \%$ of the cells in cultures prepared with the decantation step proved to be B cells (Fig. 1).

\section{Virus}

Reovirus type 3 (Abney strain) previously passaged 12 times in cultures of Rhesus monkey kidney cells was originally obtained from the American Type Culture Collection (ATCC), Rockville, Maryland, USA. This prototype virus was serially passaged in human pancreatic B cell cultures using a virus to cell ratio of 10:1. Each passage of the virus was frozen and used for experiments as described in Results. In addition, reovirus type 3 previously passaged 20 times in cultures of murine pancreatic $B$ cells in our laboratory [10] was also used for comparison against the human $B$ cell passaged virus.

\section{Plaque Assay}

The infectious titre of reovirus type 3 was determined by inoculating confluent L-929 cell monolayers ( $60 \mathrm{~mm}$ dishes) with $0.2 \mathrm{ml}$ of appropriate dilutions of the virus sample. After adsorption for $1 \mathrm{~h}$ at $37^{\circ} \mathrm{C}$, the monolayers were overlaid with agarose medium $[1 \%$ (w/v) agarose with Eagle's MEM and 5\% (v/v) fetal bovine serum]. Monolayers were stained 6 days later with $1: 40,000$ dilution of neutral red. Plaques were counted within $24 \mathrm{~h}$, and the virus titre expressed as plaque-forming units (pfu/ml).

\section{Double-labelled Immunofluorescent Antibody Technique}

Antibody to reovirus type 3 was prepared by repeated IP inoculation of 6 week old guinea pigs with $10^{6} \mathrm{pfu}$ of reovirus type 3 at weekly intervals for two weeks. Serum was collected seven days after the final immunization. The $50 \%$ neutralization titre of the antiserum to reovirus type 3 was $1: 1000$. The $\gamma$-globulin fraction of the serum, purified by ammonium sulphate precipitation and DEAE cellulose column chromatography, was conjugated with FITC [14]. Unconjugated FITC was removed by gel filtration through Sephadex G-25. The labelled $\gamma$-globulin was then adsorbed with acetone-treated mouse liver powder to eliminate non-specific fluorescence. The specificity of the labelled antiserum was established by inhibition tests using unlabelled antisera to reovirus type 3 .

The $\gamma$-globulin fraction of antibody to porcine insulin, obtained from Miles Laboratories, Elkhart, Ind., was labelled with TRITC [14]. The specificity of this labelled antibody was demonstrated by staining frozen acetone-fixed sections of human pancreas as previously described $[8,9]$. Only insulin-containing $\mathbf{B}$ cells in the islets stained bright orange, while the surrounding acinar cells did not stain. Absorption of the labelled antibody with purified porcine insulin completely blocked staining. Furthermore, as a control for specificity, it was found that diploid human fibroblast cells (WI-38) were unstained (Fig. 1B) when tested with TRITC-labelled anti-insulin antibody. In addition, none of the 
Table 1. Host specificity in susceptibility to reovirus ${ }^{\mathrm{a}}$

\begin{tabular}{|c|c|c|c|c|c|c|}
\hline Donor $^{b}$ & Years & Virus & $\begin{array}{l}\text { No. of rhodamine } \\
\text { positive cells }{ }^{c}\end{array}$ & $\begin{array}{l}\text { No. of fluorescein } \\
\text { positive cells }{ }^{d}\end{array}$ & $\begin{array}{l}\text { No. of both } \\
\text { positive cells }\end{array}$ & $\begin{array}{l}\% \text { of virus-infected } \\
\text { B cells }\end{array}$ \\
\hline \multirow[t]{2}{*}{1} & 17 & $N P^{g}$ & 61 & 179 & 3 & 5 \\
\hline & & $\mathrm{MBP}^{\mathrm{h}}$ & 79 & 185 & 4 & 5 \\
\hline \multirow[t]{2}{*}{2} & 40 & NP & 65 & 192 & 4 & 6 \\
\hline & & MBP & 81 & 241 & 6 & 7 \\
\hline \multirow[t]{2}{*}{3} & 24 & NP & 69 & 149 & 4 & 6 \\
\hline & & MBP & 65 & 152 & 4 & 6 \\
\hline \multirow[t]{2}{*}{4} & 18 & NP & 83 & 158 & 6 & 7 \\
\hline & & MBP & 103 & 186 & 8 & 8 \\
\hline
\end{tabular}

a The data represent observations accumulated from 3 or 4 coverslips in each of the groups

b All donors were male caucasian

c Insulin-containing B cells stained with rhodamine-labelled anti-insulin antibody

d Reovirus-infected cells stained with fluorescein-labelled anti-reovirus type 3 antibody

e Reovirus-infected insulin-containing B cells stained with both antibodies

${ }^{f}$ Percent of both positive cells $(\mathrm{f}=\mathrm{e} / \mathrm{c}$ )

g Unpassaged reovirus type 3 (stock virus from ATCC)

h Murine pancreatic B cell passaged reovirus type 3

cells stained positive when uninfected human pancreatic cells were stained with FITC-labelled anti-reovirus antibody.

To identify reovirus type 3 infected B cells, cells grown on coverslips were infected for two days and then fixed in acetone and stained with both TRITC-labelled anti-insulin antibody and FITClabelled anti-reovirus antibody overnight at $4^{\circ} \mathrm{C}$. Coverslips then were washed three times with PBS, mounted with Elvanol [11] and examined for immunofluorescence with a Zeiss microscope illuminated by an HBO 200 mercury lamp. Double-stained cells were identified by examining the coverslips first with rhodamine filters (BP 546/9 excitation filter and an LP 590 barrier filter), and then with fluorescein filters (KP 490 and BG 12 excitation filters and an LP 528 barrier filter). About 150-300 insulin-containing B cells were examined.

\section{Measurement of Immunoreactive Insulin}

Monolayers of human pancreatic B cells were maintained in Eagle's medium containing glucose, $100 \mathrm{mg} / 100 \mathrm{ml}$ for three days before infection with virus $[9,15]$. Insulin was extracted from the monolayers at different times after infection as well as from uninfected controls by methods described elsewhere [16]. Extracellular insulin was measured from supernatant samples from the media of the monolayer cultures (triplicate). The concentration of immunoreactive insulin was measured by radioimmunoassay with porcine insulin used as a standard [17].

\section{Statistical Analysis}

The statistical significance of the differences between the means of the sample groups was tested by Student's t-test with the Welch adjustment for unequal variances where necessary [18]. The significance level of $p<0.001$ was used as a criterion of differences.

\section{Results}

Susceptibility of Human B Cells to Unpassaged Reovirus Type 3

Cultures enriched in human B cells were grown on coverslips and inoculated with reovirus type 3
(Abney strain) at a virus-to-cell ratio of $1: 1$. Their susceptibility to infection was determined by the double-labelled immunofluorescent antibody technique. Human B cells were found to be relatively resistant to reovirus type 3 (Table 1 ). At 2 days after infection, approximately $6 \%$ of the insulin-containing B cells contained viral antigens. There was no significant difference in the susceptibility of B cells obtained from different human pancreases to both the unpassaged and the murine $B$ cell passaged reovirus type 3 (Table 1).

\section{Passage of Reovirus Type 3 in Human B Cell Cultures}

Reovirus type 3 was serially passaged in human B cell cultures. Virus was harvested $72 \mathrm{~h}$ after infection, and the titre of infectious virus was determined. Virus titres in cultures showed that the peak titre rose from $8.0 \times 10^{4} \mathrm{pfu} / \mathrm{ml}$ (1st passage) to $4.9 \times 10^{6}$ $\mathrm{pfu} / \mathrm{ml}$ (5th passage). Since these cultures were not pure $B$ cells, an increase in viral titre cannot be only attributed to replication of the virus in B cells. By use of the double-labelled immunofluorescent antibody technique, the percent of infected $B$ cells was determined. Figures $2 \mathrm{~A}, \mathrm{~B}$ and $\mathrm{C}$ are photomicrographs of human pancreatic cell cultures infected with the fifth passage of reovirus type 3 and stained $30 \mathrm{~h}$ later with TRITC-labelled anti-insulin antibody and FITClabelled anti-reovirus type 3 antibody.

When rhodamine filters were used to examine the cells (Fig. 2A), a diffuse orange colour was found in the cytoplasm but not in the nucleus. When the same three cells were examined for viral antigens with fluorescein filters (Fig. 2B), a green colour was seen in the cytoplasm. Viral antigens were not found in the nucleus, but they did appear to be relatively evenly distributed in the cytoplasm. Fig. 2B also shows 

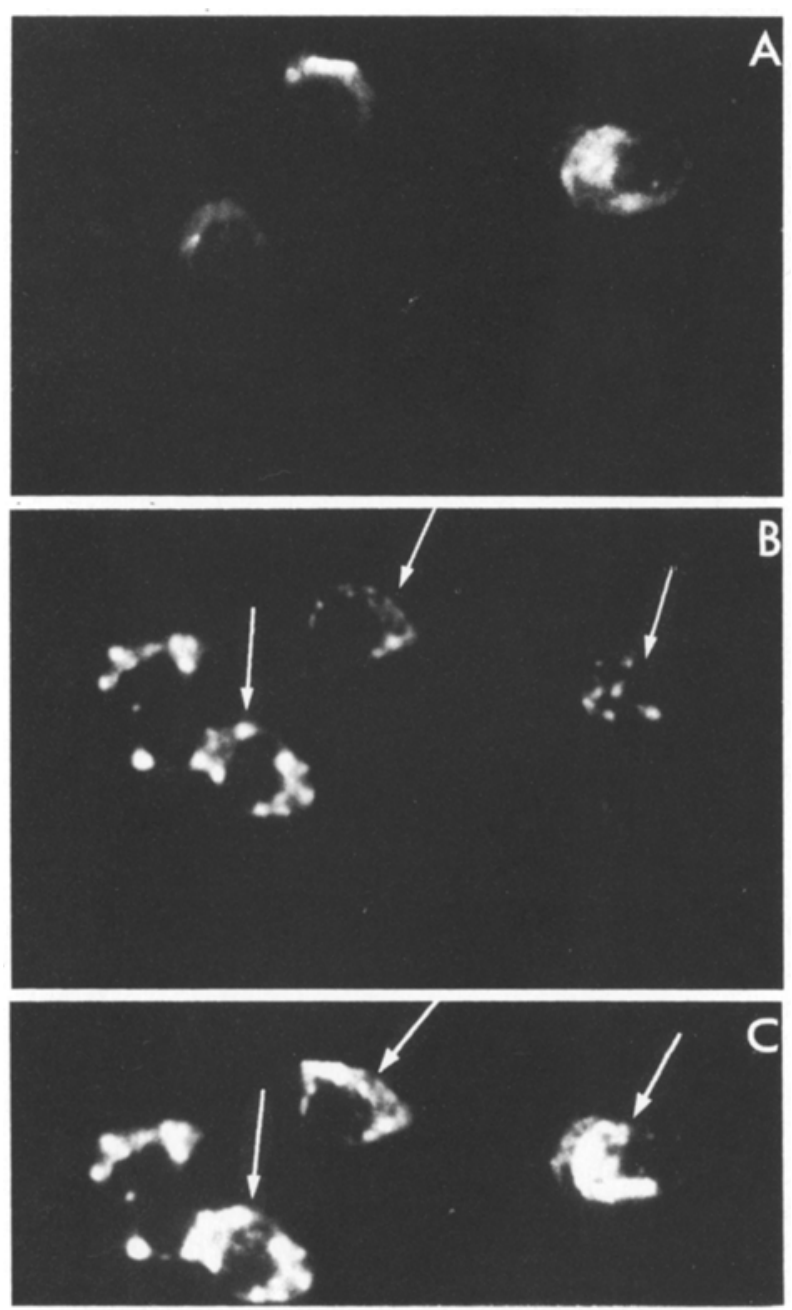

Fig. 2 A-C. Human pancreatic cell cultures infected with reovirus type 3 at a virus-to-cell ratio of $1: 1$. At the end of $30 \mathrm{~h}$, the cultures were stained with TRITC-labelled anti-insulin and FITClabelled anti-reovirus antibody. A Photograph taken with rhodamine filters. B Photograph of same area, but taken with fluorescein filters. Arrows point to same cells as seen in Figure $2 \mathrm{~A}$. C Photograph of same area, but taken first with rhodamine filters and then with fluorescein filters. Arrows point to same cells as seen in Figure $2 \mathrm{~A}(\times 720)$

reovirus-antigens in two adjacent cells. The lack of fluorescence in the corresponding positions in Fig. $2 \mathrm{~A}$ when the rhodamine filters were used indicates that these cells did not contain insulin, and probably represent one of the other cell types (e.g., $A, D$, pancreatic polypeptide-producing, acinar, ductal or fibroblasts) present in the culture. Fig. 2C shows three insulin-containing $B$ cells infected with reovirus type 3 ( 5 th passage) identified by the presence of orange and green fluorescence in the cytoplasm.

Table 2 shows the effect of repeated passage of reovirus type 3 on the infectivity to insulin-contain-
Table 2. The effect of passages of reovirus on infectivity to human $\mathrm{B}$ cells ${ }^{\mathrm{a}}$

\begin{tabular}{llllll}
\hline $\begin{array}{l}\text { Number } \\
\text { of pas- } \\
\text { sages }\end{array}$ & $\begin{array}{l}\text { Total no. } \\
\text { of cells } \\
\text { exam- } \\
\text { ined }\end{array}$ & $\begin{array}{l}\text { No. of } \\
\text { rhodam- } \\
\text { ine posi- } \\
\text { tive cells }\end{array}$ & $\begin{array}{l}\text { No. of } \\
\text { fluores- } \\
\text { cein } \\
\text { positive } \\
\text { cells }\end{array}$ & $\begin{array}{l}\text { Number } \\
\text { of both } \\
\text { positive } \\
\text { cells }\end{array}$ & $\begin{array}{l}\text { Percent } \\
\text { of virus- } \\
\text { infected } \\
\text { B cells }\end{array}$ \\
\hline $0^{\mathrm{b}}$ & 1390 & 278 & 678 & 17 & 6 \\
1 & 884 & 172 & 389 & 12 & 7 \\
3 & 790 & 157 & 327 & 19 & 12 \\
5 & 960 & 193 & 405 & 52 & 27 \\
\hline
\end{tabular}

* The different passages of reovirus type 3 were inoculated into the monolayers of pancreatic $B$ cell cultures and stained with rhodamine-labelled anti-insulin antibody and fluorescein-labelled anti-reovirus antibody

b Unpassaged reovirus type 3 (stock virus obtained from ATCC)

Table 3. The effect of virus passages on the intra- and extracellular insulin levels in human pancreatic B cell cultures three days after infection $^{\mathrm{a}}$

\begin{tabular}{lll}
\hline Passage number & $\begin{array}{l}\text { Intracellular IRI } \\
\text { (ng/ml) }\end{array}$ & $\begin{array}{l}\text { Extracellular IRI } \\
\text { (ng/ml) }\end{array}$ \\
\hline Uninfected control & $911 \pm 11^{\mathrm{b}}$ & $415 \pm 9$ \\
$0^{\mathrm{c}}$ & $855 \pm 14$ & $374 \pm 3$ \\
1 & $788 \pm 42$ & $375 \pm 3$ \\
3 & $576 \pm 4$ & $296 \pm 13$ \\
5 & $358 \pm 41$ & $220 \pm 8$ \\
\hline
\end{tabular}

a The concentration of immunoreactive insulin (IRI) in human pancreatic $B$ cell cultures infected with different passages of reovirus type 3 for three days. Approximately $8 \times 10^{5}$ cells were inoculated with the virus at a virus-to-cell ratio of 10:1 after each passage of virus was concentrated. Statistically significant $(p<0.001)$ differences in both intracellular and extracellular IRI were obtained between (1) passages 1 and 5 ; (2) uninfected controls and passage 3 ; and (3) uninfected controls and passage 5

b Mean \pm standard deviation (SD)

c Unpassaged reovirus type 3 (stock virus from ATCC)

ing B cells. The percentage of infected B cells increased from 6 to $27 \%$ by the 5 th passage. The effect of different passages of reovirus type 3 on insulin content is shown in Table 3. Intracellular insulin in cultures (triplicate) containing approximately $8 \times$ $10^{5}$ cells was $911 \pm 11 \mathrm{ng} / \mathrm{ml}$ in the uninfected cultures. At three days after infection, there was relatively little change in immunoreactive insulin in cultures inoculated with unpassaged reovirus type 3 . However, the intracellular immunoreactive insulin significantly decreased $(p<0.001)$ in cultures inoculated with fifth passaged reovirus type 3 . The concentration of extracellular insulin roughly paralleled the decrease in the intracellular insulin content. 
Table 4. The concentration of intra- and extracellular immunoreactive insulin (IRI) in human B cell cultures infected with the fifth passaged reovirus type 3

\begin{tabular}{lllll}
\hline $\begin{array}{l}\text { Days after } \\
\text { infection }\end{array}$ & Intracellular IRI $(\mathrm{ng} / \mathrm{ml})$ & & Extracellular IRI (ng/ml) \\
\cline { 2 - 3 } & Infected cultures & Uninfected cultures & & Infected cultures \\
\hline $0^{\mathrm{a}}$ & $1154 \pm 85^{\mathrm{b}}$ & & $453 \pm 11$ & Uninfected cultures \\
1 & $804 \pm 38$ & $1054 \pm 51$ & $473 \pm 4$ & $445 \pm 6$ \\
2 & $\mathrm{ND}^{\mathrm{c}}$ & $\mathrm{ND}$ & $493 \pm 11$ & $452 \pm 5$ \\
3 & $443 \pm 38$ & $943 \pm 13$ & $284 \pm 10$ & $427 \pm 8$ \\
5 & $353 \pm 29$ & $800 \pm 12$ & $231 \pm 11$ & $403 \pm 6$ \\
7 & $287 \pm 13$ & $760 \pm 29$ & $195 \pm 7$. & $387 \pm 2$ \\
\hline
\end{tabular}

a Before infection

b Mean \pm SD

${ }^{c}$ Not done

\section{Measurements of Immunoreactive Insulin in Pancreatic B Cell Cultures Infected with Reovirus Type 3 (5th Passage)}

The effect of reovirus type 3 on intracellular and extracellular insulin is shown in Table 4 . Insulin in cultures (triplicate) containing about $10^{6}$ cells was $1154 \pm 86 \mathrm{ng} / \mathrm{ml}$ at the time of viral infection. Within 3 days after inoculation, immunoreactive insulin declined to $443 \pm 38 \mathrm{ng} / \mathrm{ml}$, which was less than $50 \%$ of the uninfected controls. The concentration of insulin in the extracellular fluid increased slightly during the first 2 days of the infection, probably reflecting release from damaged $B$ cells. The concentration of extracellular insulin then declined, roughly paralleling the decrease in the intracellular insulin content. Analysis of the data from these experiments revealed statistically significant differences $(p<0.001)$ between the infected and uninfected groups on days 3 , 5 and 7 in intracellular insulin and on days 5 and 7 in extracellular insulin.

\section{Light Microscopy}

By light microscopy, approximately $30-40 \%$ of the reovirus (5th passage) inoculated monolayers were destroyed within $72 \mathrm{~h}$ after infection, while the uninfected monolayers showed no evidence of cytopathology. Infectivity assays revealed a steady increase in viral titre, peaking at about $5 \times 10^{6} \mathrm{pfu} /$ $\mathrm{ml} 72 \mathrm{~h}$ after infection.

\section{Discussion}

We have shown for the first time that the capacity of a virus to infect human pancreatic $B$ cells can be enhanced by repeated passage in cultures. In the present study, only $6 \%$ of cultured human pancreatic $B$ cells were susceptible to infection by unpassaged and murine B cell-passaged reovirus type 3 (when inocu- lated at a virus-to-cell ratio of $1: 1$ ), as compared to $60 \%$ for unpassaged mumps [8], $30 \%$ for unpassaged Coxsackie virus B3 [9], and $37 \%$ for a diabetogenic variant of Coxsackie virus $B 4$ isolated from the pancreas of a child with diabetic ketoacidosis [7]. However, serial passage of reovirus type 3 in human $B$ cell cultures increased the percentage of infected $B$ cells to $27 \%$. Adaptation of reovirus to infect human B cells was also reflected by immunochemical tests. Immunoreactive insulin levels in the human B cell cultures significantly decreased when infected with passaged virus as compared to unpassaged reovirus or murine B cell-passaged virus.

The precise mechanism by which serial passage of reovirus type 3 in cultures enriched for human B cells enhances its infectivity is not known. The two most likely possibilities are selection of variants of human B-cell tropic virus and non-genetic adaptation of reovirus type 3 to human $B$ cells. Selection of variants could have occurred in two ways. First, the original stock virus pool may have contained three populations of virus: one tropic for human B cells; one tropic for mouse B cells [10]; and the other not tropic for either. Growing the stock virus in cultures enriched for human B cells may have favoured the replication of the human B-tropic virus. Similarly, passaging the stock virus in murine $B$ cell cultures may have enhanced the multiplication of mouse Bcell tropic virus [10]. Second, mutation or recombination may have taken place during serial passage of the virus in cultures, and the presence of human $B$ cells may have favoured the selection of mutated or recombinated B-cell tropic virus. Alternatively, nongenetic adaptation may have occurred because of host-controlled alterations in viral antigen or coat. Thus, the capacity of the virus to bind to human $B$ cells would be increased. In any event, it may be possible to distinguish between a stable mutant and non-genetic adaptation by plaque-purifying the virus [19] and by testing the virus in B cell cultures derived from humans and mice. 
Neither the present study with human B cell-passaged reovirus type 3 nor earlier studies with mumps [8] and Coxsackie virus B3 [9] proves that any of the viruses can actually infect and destroy $B$ cells in vivo. It is known that some viruses will grow in cultured cells derived from animals that are resistant to infection [20-24]. Differences in susceptibility to in vitro and in vivo infection may be related to the host defence mechanisms, induction of viral receptors, and/or the requirement for cell division. Thus, the in vitro susceptibility of $B$ cells may not be a true reflection of their in vivo susceptibility. Nonetheless, when Coxsackie viruses B3 and B4 and reovirus type 3 were passaged multiple times in murine pancreatic $B$ cell cultures, these viruses infected and destroyed B cells to produce a diabetes-like syndrome in susceptible mice $[10,25,26]$. These studies suggest that under appropriate circumstances, a number of viruses can infect and destroy insulin-producing $B$ cells. The circumstances which might lead to the generation of a large number of $\mathrm{B}$-cell tropic viruses in a susceptible host are not known. Recently, a variant of Coxsackie virus B4 isolated from the pancreas of a child with diabetic ketoacidosis was shown to infect cultured human $\mathbf{B}$ cells prepared from the pancreas of a non-diabetic [7]. These studies showed that, at least in animal models, the in vitro susceptibility of $B$ cells to infection by virus reflected the diabetogenic capability of the virus in vivo. However, it is not known if B-cell tropic variants of reovirus type 3 can infect human B cells in vivo and cause abnormal glucose metabolism in man.

These data suggest that B-cell tropic variants of reovirus type 3 can be selected by repeated passaging in human B cell cultures. It lends further support to the idea that if some cases of human IDD are caused by viruses, the passage history of the virus may play an important role.

\section{References}

1. Gundersen $E$ (1927) Is diabetes of infectious origin? J Infect Dis 41: 197-202

2. Sultz HA, Hart BA, Zielezny M, Schlesinger ER (1975) Is mumps virus an etiologic factor in juvenile diabetes mellitus? J Pediatr 86: 654-656

3. Khakpour M, Nik-Akhtar B (1975) Diabetes mellitus following a mumps epidemic. J Trop Med Hyg 78: 262-263

4. Gamble DR, Taylor KW, Cummings H (1973) Coxsackie viruses and diabetes mellitus. Br Med J IV: 260-262

5. Notkins AL (1977) Virus-induced diabetes mellitus - Brief review. Arch Virol 54: 1-17

6. Craighead JE (1975) The role of viruses in the pathogenesis of pancreatic disease and diabetes mellitus. Prog Med Virol 19: 161-214

7. Yoon JW, Austin M, Onodera T, Notkins AL (1979) Virusinduced diabetes mellitus: Isolation of a virus from the pancreas of a child with diabetic ketoacidosis. N Engl J Med 300: 1173-1179
8. Prince G, Jenson AB, Billups L, Notkins AL (1978) Infection of human pancreatic beta cell cultures with mumps virus. Nature 271: 158-161

9. Yoon JW, Onodera T, Jenson AB, Notkins AL (1978) Virusinduced diabetes mellitus XI. Replication of coxsackie B3 virus in human pancreatic beta cell cultures. Diabetes 27: 778-781

10. Onodera T, Jenson AB, Yoon JW, Notkins AL (1978) Virusinduced diabetes mellitus: Reovirus infection of pancreatic B cells in mice. Science 201: 529-531

11. Yoon JW (1978) Method for cultivation and identification of human pancreatic beta cells. TCA Manual 4: 885-888

12. Leiter EH, Coleman DL, Waymouth C (1974) Cell culture of the endocrine pancreas of the mouse in chemically defined media. In Vitro 9: 421-433

13. Braaten JT, Jarlfords U, Smith DC, Mintz DH (1975) Purification of monolayer cell cultures of the endocrine pancreas. Tissue Cell 7: 747-762

14. Kawamura A Jr (1977) Fluorescent antibody techniques and their applications, second ed. Tokyo, University of Tokyo Press

15. Yoon JW, Notkins AL (1976) Virus-induced diabetes mellitus VI. Genetically determined host differences in the replication of encephalomyocarditis virus in pancreatic beta cells. J Exp Med 143: 1170-1185

16. Davoren PR (1962) The isolation of insulin from a single cat pancreas. Biochim Biophys Acta 63: 150-153

17. Hales CN, Randle PJ (1963) Immunoassay of insulin with insulin-antibody precipitate. Biochem J 88: 137-146

18. Brownlee KA (1965) Statistical theory and methodology in science and engineering. John Wiley and Sons, New York

19. Yoon JW, McClintock PR, Onodera T, Notkins AL (1980) Virus-induced diabetes mellitus. Inhibition by a nondiabetogenic variant of encephalomyocarditis virus. J Exp Med 152: 878-892

20. McLaren LC, Holland JJ, Syverton JT (1959) The mammalian cell-virus relationship. I. Attachment of poliovirus to cultivated cells of primate and non-primate origin. J Exp Med 109: 475-485

21. Holland JJ, McLaren LC (1959) The mammalian cell-virus relationship. II. Adsorption, reception and eclipase of poliovirus by Hela cells. J Exp Med 109: 487-504

22. Holland JJ (1961) Receptor affinities as major determinants of enterovirus tissue tropisms in humans. Virology 15: 312-326

23. Casto BC, Hammon WMcD (1969) Correlation between propagation of a bovine enterovirus and development of receptor-like material in tissue mince. Proc Soc Exp Biol Med 132: $154-160$

24. Kunin CM (1964) Cellular susceptibility to enteroviruses. Bacteriol Rev 28: 382-390

25. Yoon JW, Onodera T, Notkins AL (1978) Virus-induced diabetes mellitus. XV. Beta cell damage and insulin-dependent hyperglycemia in mice infected with Coxsackie virus B4. J Exp Med 148: 1068-1080

26. Stoneback TA, Crowell RL (1977) A Coxsackie virus B3 variant cytopathic for pancreatic beta cells (Abstract). Annual Meeting Am Soc Microbiol 326

Received: April 1, 1980,

and in revised form: November 4, 1980

Dr. Ji-Won Yoon

Laboratory of Oral Medicine, NIDR

National Institutes of Health

Building 30, Room 121

Bethesda, MD 20205

USA 